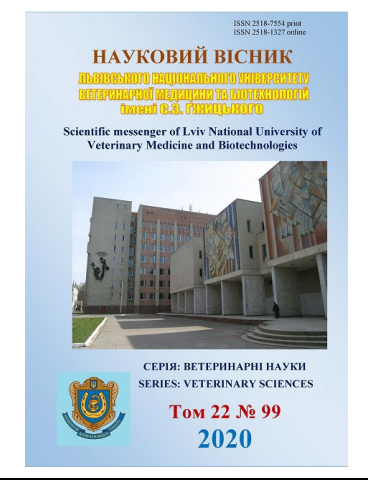

\author{
Науковий вісник Дьвівського національного університету \\ ветеринарної медицини та біотехнодогій імені С.3. Гжицького. \\ Серія: Ветеринарні науки \\ Scientific Messenger of Lviv National University \\ of Veterinary Medicine and Biotechnologies. \\ Series: Veterinary sciences
}

UDC 616.022.085.33

\title{
Study of the toxic effect of the drug "Incombivit"
}

\author{
T. M. Kaliuzhna, H. A. Fotina \\ Sumy National Agrarian University, Sumy, Ukraine
}

Article info

Received 01.09.2020 Received in revised form 30.09.2020

Accepted 01.10.2020

Sumy National Agrarian University, G. Kondratieva Str., 160 Sumy, 40000, Ukraine. Tel.: +38-066-862-04-31 E-mail: ktana0081@gmail.com
Kaliuzhna, T. M., \& Fotina, H. A. (2020). Study of the toxic effect of the drug "Incombivit". Scientific Messenger of Lviv National University of Veterinary Medicine and Biotechnologies. Series: Veterinary sciences, 22(99), 24-28. doi: 10.32718/nvlvet9904

Modern veterinary medicine has made great strides in the prevention and treatment of various diseases, largely through the availability of highly effective drugs. One of the major challenges to development of effective, safe, competitive drugs in Ukraine is the creation of an effective system of pre-clinical trials that meet international standards. The toxicity study is a mandatory phase trials of new drugs. The drug "Inkombivit" accommodates only available endogenous biologically active substances, which are natural feed ingredients for animals and are naturally present in animal tissues. All active pharmaceutical ingredients used in drug "Inkombivit", by the EU regulation No. 37/2010 related to non-hazardous for animals and people compounds. The LDso of most active pharmaceutical ingredients included in the drug "Incombivit" for mice when administered orally ranges from 5000 to $10000 \mathrm{mg} / \mathrm{kg}$ body weight, except for some active pharmaceutical ingredients when they are contained in milligram amounts in 1 liter of the drug, for which $L D_{50}$ less than $1000 \mathrm{mg} / \mathrm{kg}$ body weight of animals. Incombivit is a combination drug that contains fat- and water-soluble vitamins, trace elements and amino acids that normalize metabolism, increase overall resistance, improve productivity, safety and reproductive functions of animals. Acute toxicity of the drug was studied on 50 white mice weighing $19-21 \mathrm{~g}$ and on 20 white rats weighing 250-295 g. The animals were kept in accordance with sanitary norms and rules on a standard diet (compound feed) adopted in the vivarium. The acute $L D_{50}$ of Incombivit for a single oral administration is $7500 \pm 229.95 \mathrm{mg} / \mathrm{kg}$ body weight for mice and $6250 \pm 375.50 \mathrm{mg} / \mathrm{kg}$ body weight for rats. Incombivit can be classified as hazard class 4 according to the International Standard GOST 12.1.007-76 and to category 5 according to the International Global Harmonized System (GHS) classification, as its LD50 for mice and rats with a single oral administration exceeds $5000 \mathrm{mg} / \mathrm{kg}$ body weight.

Key words: preclinical studies of drugs, vitamins, trace elements, amino acids, immune resistance, metabolism, toxicity, drug "Incombivit".

\section{Вивчення токсичної дії препарату “Інкомбівіт”}

\author{
Т. М. Калюжна, Г. А. Фотіна
}

Сумський національний аграрний університет, м. Суми, Украӥна

\footnotetext{
Сучасна ветеринарна медицина досягла великих успіхів у профілактиці та лікуванні різних захворювань багато в чому завдяки наявності високоефективних лікарських препаратів. Одним з найважливіших завдань на шляху розробки ефективних, безпечних конкурентоспроможних ліків в Украӥні є створення ефективної системи доклінічних випробувань, які відповідають міжнародним стандартам. Вивчення токсичності є обов'язковим етапом дослідження нових лікарських засобів. Препарат "Інкомбівіт" вміщує лише ендогенно доступні біологічно активні речовини, які є природними компонентом кормів для тварин та природно присутні в тканинах тварин. Всі активні фармацевтичні інгредієнти, що входять до препарату “Інкомбівіт”, регламентом Свропейського Союзу № 37/2010 зараховані до нешкідливих для організму тварин та людей сполук, для яких немає потреби встановлення максимально допустимих рівнів у продуктах тваринництва та проводити моніторинг їх залишків. LD5о більшості активних фармацевтичних інгредієнтів, що входять до препарату “Інкомбівіт”, для мишей при пероральному введенні коливаються від 5000 до 10000 мг/кг маси тіла, за винятком окремих активно фармачевтичних інгредієнтів при їх вмісті в міліграмових кількостях у 1 л препарату, для яких LD5о менші ніж 1000 мг/кг маси тіла тварин. "Інкомбівіт” - комбінований препарат, який містить жиро- та
} 
водорозчинні вітаміни, мікроелементи та амінокислоти, щзо нормалізують обмін речовин, підвищують загальну резистентність, покрашують продуктивність, збереженість та репродуктивні функції тварин. Гостру токсичність препарату вивчали на 50 білих мишах масою тіла 19-21 г. та на 20 білих білих щурах масою 250-295 г. Тварин утримували згідно з санітарними нормами $і$ правилами на стандартному раціоні, (комбікормі), прийнятому у віварії. LD5о препарату “Інкомбівіт” при одноразовому пероральному введенні становить $7500 \pm 229,95$ мг/кг маси тіла для мишей та 6250 \pm 375,50 мг/кг маси тіла для шурів. Препарат "Інкомбівіт” можно зачислити до 4 класу небезпеки згідно з Міжнародним стандартом ГОСТ 12.1.007-76 та до категорії 5 за Міжнародною глобальною класифікацією Global Harmonized System, (GHS), оскільки його LD5о для мишей та щурів при одноразовому пероральному введенні перевищує 5000 мг/кг маси тіла.

Ключові слова: доклінічні дослідження ліків, вітаміни, мікроелементи, амінокислоти, імунна резистентність, обмін речовин, токсичність, препарат “Інкомбівіт”.

\section{Вступ}

Птахівництво в Україні є однією 3 найбільш інтенсивних і динамічних галузей сільськогосподарського виробництва, яке має усі можливості в короткі строки збільшити виробництво дієтичних висококалорійних продуктів - яєць і м'яса птиці для забезпечення потреб населення України. Однією з основних причин, що зумовила спад виробництва продукції птахівництва, $\epsilon$ недостатня збалансованість раціонів як за основними елементами живлення, так і за біологічно активними речовинами. Дані причини у поєднанні з іншими факторами створюють дисбаланс між організмом птиці і навколишнім середовищем, знижують імунобіологічну реактивність і негативно позначаються на продуктивності та відтворювальних функціях (Bushujeva, 2015).

Ринок ветеринарних препаратів України активно поповнюється ветеринарними лікарськими засобами та кормовими добавками як іноземного, так і вітчизняного виробництва, дія яких спрямована на поліпшення функціонування імунної системи, корекцію імунного статусу організму. Впровадження цих препаратів у практику ветеринарної медицини вимагає ретельної експертизи, відтворення методів контролю, комплексного методичного підходу з використанням основних і допоміжних тестів, котрі грунтуються на засадах ветеринарної фармакології, токсикології, експериментальної імунології, імунохімії, гематології, біохімії (Zhyla et al., 2013).

Сучасна ветеринарна медицина досягла великих успіхів у профілактиці та лікуванні різних захворювань багато в чому завдяки наявності високоефективних лікарських препаратів. Одним 3 найважливіших завдань на шляху розробки ефективних, безпечних конкурентоспроможних ліків в Україні $є$ створення ефективної системи доклінічних випробувань, які відповідають міжнародним стандартам.

Більшість наявних лікарських засобів впливають на імунну систему, зазвичай вони стимулюють або пригнічують імунну реакцію. Виходячи 3 цього, варто розділити всі лікарські засоби на ті, що безпосередньо впливають на імунологічні механізми і призначені саме для цього, і на ті препарати, вплив яких на імунну систему має побічний або опосередкований характep (Kosenko et al., 2004; Zhyla et al., 2013).

Часто для підвищення резистентності організму застосовуються кормові добавки, що містять макрота мікроелементи, біологічно активні речовини. Відомо, що раціони 3 дефіцитом Цинку викликають у тварин пригнічення гуморального і значне зниження реакцій клітинного імунітету. Препарати Міді, Марганцю, Заліза стимулюють фактори природної резистентності. Однак надлишок макро- і мікроелементів не менш шкідливий, ніж їхня недостатність (Kosenko et al., 2004).

Препарат "Інкомбівіт" вміщує лише ендогенно доступні біологічно активні речовини, які $є$ природними компонентом кормів для тварин та природно присутні в тканинах тварин. Всі активні фармацевтичні інгредієнти, що входять до препарату “Інкомбівіт”, регламентом Європейського Союзу № 37/2010 зачислені до нешкідливих для організму тварин та людей сполук, для яких немає потреби встановлення максимально допустимих рівнів у продуктах тваринництва та проводити моніторинг їхніх залишків. LD $_{50}$ більшості активних фармацевтичних інгредієнтів, що входять до препарату “Інкомбівіт”, для мишей при пероральному введенні коливаються від 5000 до 10000 мг/кг маси тіла, за винятком окремих активно фармацевтичних інгредієнтів при їх вмісті у міліграмових кількостях в 1 л препарату, для яких $\mathrm{LD}_{50}$ менші ніж 1000 мг/кг маси тіла тварин.

Токсичність залежить від дози, як стверджував Парацельс понад 500 років тому. Однак короткочасний токсичний ефект визначається 3 використанням середньої смертельної дози $\left(\mathrm{LD}_{50}\right)$, вперше введеної Треваном в 1927 році.

Метою доклінічних досліджень ліків є одержання науковими методами оцінок та доказів їхньої ефективності та безпеки.

Препарат "Інкомбівіт” у своєму складі містить три жиророзчинні вітаміни (A, $\mathrm{D}_{3}$ та $\left.\mathrm{E}\right)$, дев'ять водорозчинних вітамінів (вітамін $\mathrm{B}_{1}$, вітамін $\mathrm{B}_{2}$, вітамін $\mathrm{B}_{6}$, вітамін $\mathrm{B}_{12}$, Д-пантенол, нікотинамід, фолієва кислота, біотин, холіну хлорид), дві незамінні (лізин та метіонін) та три ессенціальні мікроелементи (Мідь, Цинк та Манган) (Kaliuzhna, 2018; Brovafarma, 2019).

Вітамін А бере участь в окисно-відновних реакціях, регулює активність інсуліну, вуглеводний і жировий обмін, активізує метаболізм Кальцію і Магнію, засвоєння кисню в біохімічних процесах, взаємодію білків із ліпідами у клітинних мембранах, стримує утворення кератиногіалінових зерен у ліпідному шарі клітинних мембран, підтримує еластичність оболонок клітин, функціонування органів зору, шкіри, дихальних шляхів, ШКТ, матки, стимулює репродуктивні функції - спермато- та оогенез, ріст ембріонів, настання статевої зрілості, синтез статевих гормонів (Lavryshyn et al., 2016).

Вітамін $\mathrm{D}_{3}$ бере участь в обміні Кальцію і Фосфору, впливає на розвиток кісток, регулює вміст Каль- 
цію і Фосфору у крові та кістковій тканині, забезпечує їхнє фізіологічне співвідношення в організмі, впливає на тканинне дихання і окиснення вуглеводів. При зниженні вмісту Кальцію у крові тварин забезпечує його перехід 3 кісткової тканини (Martyshuk et al., 2019; 2020; Ostapyuk \& Gutyj, 2020).

Вітамін Е - антиоксидант, регулює окиснення під час біосинтезу білка, забезпечує метаболізм АТФ, захищає еритроцити від гемолізу та окиснення, запобігає окисненню жирних кислот, забезпечує стійкість i активність епітелію слизових оболонок репродуктивної системи, ШКТ і кон'юнктиви, регулює сперматогенез та зменшує кількість патологічно змінених сперматозоїдів, запобігає переродженню епітелію сім'яних канальців у самців, поліпшує запліднення і ембріональний розвиток плоду у самок.

Вітаміни групи В входять до складу різних ферментів, які беруть участь в обміні вуглеводів, ліпідів, білків, амінокислот, забезпеченні тварин енергією, еритроцитопоезі, синтезі гемоглобіну, процесах тканинного дихання, функціонуванні ЦНС, підтримці структури шкіри та зору, попередженні жирової інфільтрації печінки.

Мідь та Манган - мікроелементи, що беруть участь у гемопоезі, стимулюють синтез гемо- і міоглобіну, еритроцитопоез, входять до складу ферментів тканинного дихання і системи антиоксидантного захисту, необхідні для формування кісткової тканини.

Цинк бере участь в обміні нуклеїнових кислот i синтезі білків, впливає на основні життєві процеси кровотворення, розмноження, розвитку організму тварин, вуглеводневого та енергетичного обміну (Boiko et al., 2020).

Лізин та метіонін - незамінні амінокислоти, що входять до складу майже всіх білків, беруть участь у синтезі біологічно активних речовин, гормонів, ферментів, карнітину, холіну, фосфоліпідів, формуванні колагену (Brovafarma, 2019).

Препарат застосовують для лікування та профілактики порушень обміну речовин, гіповітамінозів, рахіту, остеодистрофії, перед- і післяродового залежування, післяродової гіпокальціємії та гіпофосфатемії, артрозу, захворювань ШКТ та дихальних шляхів, інфекційних та паразитарних захворювань, підтримання відтворної функції, стимуляції продуктивності, росту і розвитку тварин, підвищення неспецифічної резистентності, яйценосності, покращення стану шкіри та оперення, у періоди підвищеної потреби в поживних речовинах (стресові ситуації, транспортування, проведення ветеринарних заходів, зміна складу корму, високі температури), під час вагітності (друга половина) і лактації, у період вакцинації (Kaliuzhna, 2018).

Мета $i$ завдання дослідження: вивчення токсичної діï препарату "Інкомбівіт" на організм мишей при одноразовому та багаторазовому підшкірному введенні.

\section{Матеріал і методи досліджень}

Об'єктом дослідження був препарат “Інкомбівіт”, виготовлений ТОВ “БРОВАФАРМА”. Токсичність препарату “Інкомбівіт” визначали згідно 3 “Методичними вказівками з визначення токсичних властивостей препаратів, які застосовуються у ветеринарії та тваринництві” та “Доклінічними дослідженнями ветеринарних лікарських засобів” (Kotsiumbas et al., 2006).

Дослідження проводились в умовах атестованого віварію Регіонального центру РЦ “ЕКОМЕДХІМ" Сумського державного університету та Сумського національного аграрного університету (Свідоцтво про атестацію № РУ - 1396/15).

В досліді використовували препарат "Інкомбівіт" експериментальної серії 04, виготовленої ТОВ “БРОВАФАРМА” 08.2018 року.

Це комбінований препарат, який містить жиро- та водорозчинні вітаміни, мікроелементи та амінокислоти, що нормалізують обмін речовин, підвищують загальну резистентність, поліпшують продуктивність, збереженість та репродуктивні функції тварин.

Гостру токсичність препарату вивчали на 50 білих мишах масою тіла 19-21 г. та на 20 білих щурах масою 250-295 г. Тварин утримували згідно з санітарними нормами і правилами на стандартному раціоні, (комбікормі), прийнятому у віварії. Воду тварини отримували без обмежень. Перед проведенням досліджень тварин зважували. Препарат “Інкомбівіт" перед пероральним введенням тваринам інтенсивно змішували порівну з дистильованою водою. Після змішування препарат швидко вводили тваринам вранці на голодний шлунок перорально одноразово через зонд 3 канюлею в дозах 2500, 5000, 7500, 10000 та 12500 мг/кг маси тіла. Годівлю тварин розпочинали через дві години після введення препарату. За мишами вели спостереження впродовж 14 діб після введення препарату. В ході досліджень спостерігали за клінічним станом тварин, враховували їхню активність, та кількість тварин, що загинули. Результати вивчення токсичної дії препарату "Інкомбівіт" вносили в таблицю 1 та проводили розрахунок $\mathrm{LD}_{50}$ гострої препарату для мишей при пероральному введенні за Кербером. Дослідження виконувались 3 дотриманням правил Практичного керівництва ВОО3 з біологічної безпеки в лабораторних умовах.

\section{Результати та їх обговорення}

Результати вивчення гострої токсичної дії препарату "Інкомбівіт" при пероральному введені мишам та розрахунок $\mathrm{LD}_{50}$ гострої препарату для мишей при оральному введенні за Кербером становили $7500 \pm 229,95$ мг/кг маси тіла (табл. 1). 


\section{Таблиця 1}

Результати вивчення гострої токсичної дії препарату “Інкомбівіт” при пероральному введені мишам та розрахунок $\mathrm{LD}_{50}$ препарату для мишей при оральному введенні за Кербером

\begin{tabular}{lccccc}
\hline Дози, мг/кг маси тіла & 2500 & 5000 & 7500 & 10000 & 12500 \\
\hline Вижило мишей & 10 & 7 & 6 & 5 & 0 \\
Загинуло мишей & 0 & 3 & 4 & 8 & 10 \\
$\mathrm{Z}$ & 0 & 1,5 & 3,5 & 6,0 & 9,0 \\
$\mathrm{D}$ & 2500 & 2500 & 2500 & 2500 & 2500 \\
$\mathrm{Z}$ x D & 0 & 3750 & 8750 & 15000 & 22500 \\
\hline
\end{tabular}

Дозу $\mathrm{LD}_{50}$ препарату розраховували за формулою:

$\mathrm{LD}_{50}=\mathrm{LD}_{100}-(\Sigma(\mathrm{Z} \times \mathrm{D}): \mathrm{n})$ де :

$\mathrm{LD}_{100}$ - доза препарату, яка спричиняє падіж всіх тварин в групі;

$\mathrm{D}$ - інтервал між кожними двома суміжними дозами;

$\mathrm{Z}$ - середнє арифметичне з числа тварин, які загинули;

$\mathrm{n}$ - число тварин у групах.

$\mathrm{LD}_{50}=12500-((3750+8750+15000+22500): 10)$

$=12500-5000=7500$ мг/кг маси тіла.

При аналізі графіка “доза-ефективність” визначали показники $\mathrm{LD}_{16}$ та $\mathrm{LD}_{84}$, які становили 3750 та 11250 мг/кг маси тіла.

За формулою Гаддама визначали стандартну похибку LD $\mathrm{D}_{50}$ гострої токсичності препарату "Інкомбівіт” для щурів при пероральному введенні:

$\mathrm{S}=\sqrt{ }(\mathrm{K} \times \mathrm{E} \times \mathrm{D}): \mathrm{n}$, де:

$\mathrm{K}=0,564$;

$\mathrm{E}=\left(\mathrm{LD}_{84}-\mathrm{LD}_{16}\right): 2$;

$\mathrm{D}$ - інтервал між кожними двома суміжними дозами;

$\mathrm{n}$ - число тварин у групах.

$\mathrm{S}=\sqrt{ }[0,564 \times[(11250-3750): 2] \times 2500]: 10=$ $\sqrt{ }(0,564 \times 3750 \times 2500): 10=229,95$ мг/кг.

Таким чином, LD 50 препарату "Інкомбівіт" для мишей при одноразовому пероральному введенні становить $7500 \pm 229,95$ мг/кг маси тіла. Вивчення гострої токсичності препарату “Інкомбівіт” при одноразовому пероральному введенні білим щурам. Гостру токсичність препарату "Інкомбівіт" вивчали на 20 білих білих щурах масою 250-295 г. Тварин утримували згідно з санітарними нормами і правилами та на стандартному раціоні, прийнятим у віварії Центру (комбікормі). Воду тварини отримували без обмежень. Перед проведенням досліджень тварин зважували. Препарат "Інкомбівіт" перед пероральним введенням тваринам інтенсивно змішували порівну 3 дистильованою водою. Після змішування препарат швидко вводили тваринам уранці на голодний шлунок перорально одноразово через зонд з канюлею в дозах 2500, 5000, 7500 та 10000 мг/кг маси тіла. Годівлю тварин розпочинали через дві години після введення препарату. За щурами вели спостереження впродовж 14 діб після введення препарату. В ході досліджень спостерігали за клінічним станом тварин, враховували їхню активність та кількість тварин, що загинули. Результати вивчення токсичної дії препарату "Інкомбівіт” вносили в таблицю 2 та проводили розрахунок $\mathrm{LD}_{50}$ гострої токсичості препарату для білих щурів при пероральному введенні за Кербером.

\section{Таблиця 2}

Результати вивчення гострої токсичної дії препарату “Інкомбівіт” при пероральному введені щурам та розрахунок $\mathrm{LD}_{50}$ гострої препарату для щурів при оральному введенні за Кербером

\begin{tabular}{lcccc}
\hline Дози, мг/кг маси тіла & 2500 & 5000 & 7500 & 10000 \\
\hline Вижило щурів & 5 & 4 & 1 & 0 \\
Загинуло щурів & 0 & 1 & 4 & 5 \\
$\mathrm{Z}$ & 0 & 0,5 & 2,5 & 4,5 \\
$\mathrm{D}$ & 2500 & 2500 & 2500 & 2500 \\
$\mathrm{Z} \times \mathrm{D}$ & 0 & 1250 & 6250 & 11250 \\
\hline
\end{tabular}

Дозу $\mathrm{LD}_{50}$ препарату розраховували за формулою:

$\mathrm{LD}_{50}=\mathrm{LD}_{100}-(\Sigma(\mathrm{Z} \times \mathrm{D}): \mathrm{n})$, де:

$\mathrm{LD}_{100}$ - доза препарату, яка спричиняє загибель всіх тварин в групі;

$\mathrm{D}$ - інтервал між кожними двома суміжними дозами;

$\mathrm{Z}$ - середнє арифметичне з числа тварин, які загинули;

n - число дослідних тварин у групах.

$\mathrm{LD}_{50}=10000-((1250+6250+11250): 5)=$ $10000-3750=6250$ мг/кг маси тіла.
При аналізі графіка “доза-ефективність” визначали показники $\mathrm{LD}_{16}$ та $\mathrm{LD}_{84}$, які становили 3750 та 8750 мг/кг маси тіла.

За формулою Гаддама визначали стандартну похибку LD 50 гострої препарату “Інкомбівіт" для щурів при пероральному введенні:

$$
\begin{aligned}
& \mathrm{S}=\sqrt{ }(\mathrm{K} \times \mathrm{E} \times \mathrm{D}): \mathrm{n}, \text { де } \\
& \mathrm{K}=0,564 ; \\
& \mathrm{E}=\left(Л_{84}-\text { ЛД}_{16}\right): 2 \\
& \mathrm{D}-\text { інтервал між кожними двома суміжними доза- } \\
& \text { n - число тварин у групах. }
\end{aligned}
$$
ми; 
$\mathrm{S}=\sqrt{ }[0,564 \times[(8750-3750): 2] \times 2500]: 5=$ $\sqrt{ }(0,564 \times 2500 \times 2500): 5=375,50$ мг/кг.

Таким чином, $\mathrm{LD}_{50}$ гостра препарату "Інкомбівіт" для щурів при пероральному введенні становить $6250 \pm 375,50$ мг/кг маси тіла.

\section{Висновки}

1. $\mathrm{LD}_{50}$ гострої токсичності препарату "Інкомбівіт" при одноразовому пероральному введенні становить $7500 \pm 229,95$ мг/кг маси тіла для мишей та $6250 \pm 375,50$ мг/кг маси тіла для щурів.

2. На підставі отриманих результатів досліджень препарат "Інкомбівіт" необхідно віднести до 4 класу небезпеки згідно 3 Міжнародним стандартом ГОСТ 12.1.007-76 та до категорії 5 за Міжнародною глобальною класифікацією Global Harmonized System, (GHS), оскільки його $\mathrm{LD}_{50}$ для мишей та щурів при одноразовому пероральному введенні перевищує 5000 мг/кг маси тіла.

\section{References}

Boiko, O. V., Honchar, O. F., Lesyk, Y. V., Kovalchuk, I. I., \& Gutyj, B. V. (2020). Effect of zinc nanoaquacitrate on the biochemical and productive parameters of the organism of rabbits. Regulatory Mechanisms in Biosystems, 11(2), 243-248. doi:10.15421/022036.

Brovafarma (2019). Inkombivit. URL: http://brovafarma. com.ua/uk/incombivit.html (in Ukrainian).

Bushujeva, I. V. (2015). Organizacijno-ekonomichni ta farmakoekonomichni doslidzhennja rivnja farmacevtychnogo zabezpechennja preparatamy dlja ptahivnyctva. ScienceRise, 1(3), 57-61. doi: 10.15587/2313-8416.2015.36024 (in Ukrainian).

Kaliuzhna, T. M. (2018). Vyvchennja toksychnoi dii preparatu "Inkombivit" pry bagatorazovomu vvedenni. Materialy XVII Vseukrainskoi naukovopraktychnoi konferencii molodyh uchenyh. Lviv. NAAN Ukrainy, Instytut biologii tvaryn, 20(4), 106 (in Ukrainian).

Kosenko, M. V., Kocjumbas, I. Ja., Kosenko, Ju. M., ta in. (2004). Kontrol vplyvu veterynarnyh likarskyh zasobiv na stan imunitetu tvaryn. Veterynarna medycyna Ukrai'ny, 1, 43-44 (in Ukrainian).

Kotsiumbas, I. Ya., Malyk, O. H., \& Patereha, I. P. (2006). Doklinichni doslidzhennia veterynarnykh likarskykh zasobiv. Za red. I.Ya. Kotsiumbasa Lviv. Triada plius (in Ukrainian).

Lavryshyn, Y. Y., Varkholyak, I. S., Martyshuk, T. V., Guta, Z. A., Ivankiv, L. B., Paladischuk, O. R., Murska, S. D., Gutyj, B. V., \& Gufriy, D. F. (2016). The biological significance of the antioxidant defense system of animals body. Scientific Messenger LNUVMBT named after S. Z. Gzhytskyj, 18, 2(66), 100-111. doi: 10.15421/nvlvet6622.

Martyshuk, T. V., Gutyj, B. V., Vishchur, O. I., \& Todoriuk, V. B. (2019). Biochemical indices of piglets blood under the action of feed additive "Butaselmevitplus". Ukrainian Journal of Veterinary and Agricultural Sciences, 2(2), 27-30. doi: 10.32718/ujvas2-2.06.

Martyshuk, T. V., Gutyj, B. V., Zhelavskyi, M. M., Midyk. S. V., Fedorchenko, A. M., Todoriuk, V. B., Nahirniak, T. B., Kisera, Ya. V., Sus, H. V., Chemerys, V. A., Levkivska, N. D., Iglitskej, I. I. (2020). Effect of Butaselmevit-Plus on the immune system of piglets during and after weaning. Ukrainian Journal of Ecology, 10(2), 347-352. doi: 10.15421/2020_106.

Ostapyuk, A. Y., \& Gutyj, B. V. (2020). Influence of milk thistle, methifene and sylimevit on the morphological parameters of laying hens in experimental chronic cadmium toxicosis. Ukrainian Journal of Veterinary and Agricultural Sciences, 3(1), 42-46. doi: 10.32718/ujvas3-1.08.

Zakon Ukrainy (2020). "Pro zahyst tvaryn vid zhorstokogo povodzhennja". №3447-VI vid 13.02 .2020 r. URL: https://zakon.rada.gov.ua/laws/show/3447-15 (in Ukrainian)

Zhyla, M. I., Kocjumbas, I. Ja., \& Stronskyj, Ju. S. (2013). Osnovni pidhody do vyvchennja efektyvnosti veterynarnyh preparativ imunomoduljujuchoi dii. Lviv. Naukovyj visnyk LNUVMBT imeni S.Z. Gdzhyckogo, 15, 1(55), 53-59. URL: http://nbuv.gov.ua/UJRN/nvlnu_2013_15_1\%281\%29 12 (in Ukrainian). 